\title{
Göstergebilimsel Açıdan Fotoğraf İncelemesi: Pulitzer Ödüllü Savaş Fotoğrafları
}

\author{
M. Sefa Doğru (Öğr. Gör. Dr.) \\ Selçuk Üniversitesi İletişim Fakültesi \\ sefadogru@gmail.com \\ Orcid: 0000-0002-2680-888X \\ Abdulgani Arıkan (Prof. Dr.) \\ Selçuk Üniversitesi İletişim Fakültesi \\ ganiorkun@gmail.com \\ Orcid: 0000-0003-1112-2305
}

\author{
Başvuru Tarihi: 12.04.2019 \\ Yayına Kabul Tarihi: 15.05.2019 \\ Yayınlanma Tarihi: 22.07.2019
}

DOI: 10.17680/erciyesiletisim.552804

Doğru, M. S. ve Arıkan, A. (2019). Gösterge Bilimsel Açıdan Fotoğraf İncelemesi: Pulitzer Ödüllü
Savaș Fotoğrafları. Erciyes İletișim Dergisi, 6 (2), 913-928. DoI: 10.17680/erciyesiletisim.552804

Öz

İnsan ilk çağlardan bu yana tecrübelerini çizerek, kazıyarak, boyayarak veya yontarak görselleștirmeye çalışmıștır. Nihayet 19. yüz yılın ortalarında bu görselleștirmede çok fazla imkanlar sunan fotoğrafi keşfetmiştir. Fotoğraf; geleneksel teknoloji ve kimyasallar yardımı ile gelişimini sürdürürken, dijital teknolojilerle bugünkü zirvesine ulaşmıștır. Diğer yandan fotoğraf da sinema, tiyatro ve edebiyat gibi bir anlatıya sahiptir. Onu diğerlerinden farklı kılan ise anlattığı bu öyküleri yüzyıllar sonra bile izleyende, bakanda, görende hiç değişmeden göstergeler aracılığıyla bize sunabilmesidir. Bu göstergeler anlatı düzleminde genel kabul gören evrensel bir anlam düzeyine sahiptir. Kodlar, yüzyıllar geçse de tıpkı mağara duvarlarında insanın ilk çizdiği resimler kadar canlı, anlam yüklü ve derinlere indiğinizde bilişsel ve duygusal olarak bizleri derinden etkileyen bir güce sahiptir. Bunun yanında haber fotoğrafçılığı bize bir öykü anlatırken aynı zamanda bir iletiyi yaymayı amaçlar. Bu ileti açık ve anlaşılır olmalıdır. Yüzyıllardır sözcükler ve görüntülerin birleşiminden oluşan bir iletişim dili olarak fotoğraf, sürekli gelişmiş ve evirilmiştir. Tüm bu gelişmelerin etkisi altında toplumları derinden etkileyen ve hatta yönlendiren bir güce kavuşmuştur. Bu güç, fotoğrafı oluşturan imgeye yüklenen mesaj kodlarının hedef kitle tarafından hızlı, etkili ve kalıcı olarak algılanmasıyla ilgili ilgili olduğu söylenebilir. Elde edilen bulgular ve bilgiler ışığında bu çalışmada, Pulutzer Ödülü savaş fotoğraflarının görsel çözümlemesi yapılarak sahip oldukları güç incelenmiştir.

Anahtar Kelimeler: Pulutzer, Fotoğraf, Göstergebilim. 


\title{
Photograph Analysis by Semiotic Method: Pulitzer Awarded War Photos
}

\author{
M. Sefa Doğru (Lect. Ph.D.) \\ Selçuk University Faculty of Communication \\ sefadogru@gmail.com \\ Orcid: 0000-0002-2680-888X \\ Abdulgani Arıkan (Prof. Dr.) \\ Selçuk University Faculty of Communication \\ ganiorkun@gmail.com \\ Orcid: 0000-0003-1112-2305
}

Date Received: 12.04.2019

Date Accepted: 15.05 .2019

Date Published: 22.07.2019

DOI: 10.17680/erciyesiletisim.552804

\begin{abstract}
Humanity has tried to visualize its experiences by drawing, engraving, painting or sculpting since the early ages. Finally, in the middle of the 19th century, he discovered the photo that provided so many possibilities in this visualization. While photography continues its development with the help of technology and chemicals, it has acquired its current form with digital technologies. On the other hand, photography has a narrative such as cinema, theater and literature. What makes it's different from others is that these stories can be presented to us in its followers. These indicators have a universally accepted level of significance in the narrative plane. Codes. Instead, news photography opens a message after telling us a story. This message must be clear and understood. For centuries, photography has consistently developed and evolved as a communication language consisting of a combination of words and images. News photography has attained a power that influences and even directs societies under the influence of all these developments. This power may be related codes of the image which are perceived by the target audience fastly, effective and permanent in the photo. In this study, war photographs awarded by Plutzer has been analyzed by visual analysis in terms of the power they have.
\end{abstract}

Keywords: Pulutzer, Photography, Semiotics. 


\section{Giriş}

İnsan, tarihin ilk çağlarından itibaren günümüze kadar korkularını, heyecanlarını kısaca duygularını ve doğaya ait izlenimlerini kendi yorumuyla bir yüzey üzerine aktarmıștır. Bazen mağara duvarlarına, bazen bir deri parçası üzerine ve çoğunlukla da tarihsel süreç içerisinde kâğıt ve bez (tuval) üzerine boyayarak veya çizerek bu aktarım ya da görselleștirme eylemini gerçekleştirmiştir. İnsanlık en nihayetinde 1800 yılların ortalarında, ışığı ve ışığa karşı duyarlı yüzeyi kullanarak bu görselleştirme eylemini bir adım öteye taşıyarak fotoğrafı ortaya çıkarmıştır. Kılıç $(2002,13)$ yüzeye pozlama yaparak kullanan bu yeni tekniğe fotoğraf adı verildiğini vurgulamaktadır.

Fotoğrafı çok ilginç bir buluş haline getiren hammaddesinin ışık ve zaman oluşudur. Görüntüleri taşımaya yarayan fotoğraf makinasının çalışma ilkesi de icat edildiğinden bu yana hiç değişmemiştir (Derman, 1991, 65).

Teknik gelişmeler fotoğrafı günümüzün en popüler görselleştirme aracı haline getirirken; bu görselleştirme çabasının yarattığı imgelerin taşıdığı mesajlar ve etkisi de birçok iletişim çalışmasında da dikkatle ele alınmaktadır.

Haberi yansıtan her fotoğraf, yakaladığı zamanın ve yansıttığı toplumun bir bütün olarak göstergesidir. Fotoğrafın teknik okumamaları ve sanatsal analizleri kadar gösterge bilimsel analizleri de göstergelerin tarihi serüvenleri içindeki mana ve ehemmiyetini ön plana çıkarmaktadır.

\section{Amaç ve Yöntem}

Bu çalışmada Pulitzer Fotoğraf Ödülü alan savaş fotoğraflarındaki imge ve anlamları ortaya konulmaya çalışılmıștır. Dolayısı ile haberi yansıtan bu fotoğrafların imge mesaj bütünlügü ile birlikte yarattığı etki anlamlandırılmaya çalışılacaktır.

Bu çalışmada haber fotoğrafçısının, görsel malzemeyi ve "anı" kaydetme arzusuyla gerçekliği fotoğrafa nasıl dönüştürdüğüne yer verildikten sonra, fotoğrafın yapısı ve estetik boyutu ele alınacaktır. 19. yüzyılın ikinci yarısından itibaren çeşitlenmeye başlayan fotoğrafçılığın "haber fotoğrafı" türünün gelişimi anlatılarak, haber fotoğrafçılığının yapısı ve niteliklerine bakılacaktır. Son olarak haber fotoğrafçılığının gelişimine büyük katkılar sağlayan "Pulitzer Ödülü" ne değinilecektir.

Araştırma 1942-2014 yılları arasında Pulitzer Fotoğraf Ödülü alan 3 savaş fotoğrafı ile sınırlandırılmıştır. Bu çalışmanın genelinde, haber fotoğrafının toplumsal etkisi göz önünde bulundurularak, Pulitzer Ödülü alan fotoğrafların seçilmesinde ve sunulmasında ön görülen niteliklerin daha iyi anlaşılması için gösterge bilimsel analiz yöntemi tercih edilmiștir.

\section{Fotoğrafın Kısa Tarihi}

Fotoğraf tarihi açısından iki nokta çok önemlidir: Yüzey üzerinde bir nesnenin görüntüsünün elde edilmesinin tarihi, bir nesnenin görüntüsünün bir yüzey üzerine kayıt edilmesi ve sabitlenmesi tarihidir. Milattan önce 5. Yüzyılda Çinli filozof Mo Ti'nin, yüzey üzerine görüntü yansıtmakla ilgili gözlemi, 11. Yüzyılda Arap astronomi bilginleri tarafından geliştirilerek güneş ve ay tutulmasını izlemek için kullanılmıștır. Karanlık bir odanın, duvarına iğne ile açılmış bir delikten nesnenin, ipek bir perde üzerine yansımasına dayanan bu teknik, Aristoteles'in Problemler adlı eserinde, Camera Obscura olarak adlandırılmaktadır. 17. yüzyılın sonlarında karanlık kutu, 
görüntülerin yüzey üzerine düşürülmesine olanak veren yapısıyla, geleceğe yön verecek ve sanatçılara yeni ufuklar açacak bir aygıt olarak, 18 yüzyılda yaygın olarak kullanılmaya başlanmıştır. Mekanik çizim için geliştirilen Camera Lucida ise, 1807 yılında İngiliz bilim adamı William Hyde Wollaston tarafından tasarlanmıştır. Bir görüntünün nesnenin üzerine kaydedilerek sabitlenmesine yönelik çalışmaların ilk somut göstergesi ise Tom Wedgood'un çalışmalarıdır. Wegwood, pozlama tekniği ile bir nesnenin görüntüsünü yüzey üzerine kaydetmeyi başarmıştır. Fotoğraf tekniği alanında yapılan daha sonraki çalışmalarda görüntünün kimyasal yollarla çoğaltılması fikri ön plana çıkmıştır. Bu teknik üzerinde çeşitli denemeler yaparak gravür kopyalamayı başaran Neipce, duyarlı yüzeyi karanlık odada pozlandırma düşüncesi üzerinde yoğunlaşmıştır ve 1816 yılında ilk sonuçları elde etmiştir (Kılıç, 2002, 13-18).

Niepce'ın duyarlı yüzeyi karanlık odada pozlandırarak ilk fotoğraf deneyimini gerçekleştirmesi sonrası Niepce ile 1829 yılında bir ortaklık anlaşması imzalayan Fransız ressam Daguerre, fotoğraf çalışmalarını daha da ilerleterek, poz süresini sekiz saatten birkaç dakikaya düşüren dagueertip adını verdiği bir yöntem geliştirmiştir (Bodur, 2005, 0-13). Daguerre'nin çektiği her bir resim biricikti; bir levhaya 1839 yılında ortalama olarak 25 altın frank ödeniyordu (Aydemir, 2013, 14).

İngiliz bilim adamı William Henry Fox Talbot, fotoğrafın daha geniş kitlelere yayılmasını sağlayan çalışmalarında, görüntüyü kâğıt üzerinde sabitleme fikrine yönelmiştir. Kâğıt üzerinde negatif görüntü elde etmeyi başaran ve aynı zamanda negatif görüntüden sayısız pozitif elde eden Talbot, fotoğrafı bir çoğaltım aracı olarak insanlığın hizmetine sunmuştur. Talbot'un geliştirdiği ve adına Kalotip (Calotype) dediği yeni yönteme Sir John Herschel, Yunanca photos 'işılk' ve grouphos 'çizmek' sözcüklerinden oluşan photography adını vermiştir. Fotoğrafçıların yenilik arayışları, albümünle hazırlanan cam levhaları ortaya çıkarmış ve çok nitelikli negatifler elde edilmiştir. Ancak albüminle hazırlanan levhaların da çok çabuk hasar görmesi ve pozlama süresinin kalotip kadar uzun olması Frederick Scott Archer'i kollodyum maddesinin keşfine itmiştir. Yaş kollodyum tekniği, dagerreyotip ve kalotipin yerini alarak 1880'e kadar çok yaygın olarak kullanılmıştır. İngiliz Richard Leach Maddox ise kuru levhaların yıllarca saklanmasına hatta pozlandırıldıktan sonra bile saklanabilmesine imkân veren bir teknik geliştirmiş, bu teknik ile birlikte kollodyum yerini jelatin maddesine bırakmıștır. Jelatin brömürle kaplı levhalar pozlama süresini saniyelere indirmiş, böylelikle fotoğrafçılar sehpalardan kurtularak makinelerini ellerinde taşımaya başlamışlardır. George Eastman, 1889 yılında gümüş bromür duyarkatıyla kaplanmış selüloit filmi geliştirmiştir. Gümüş bromür duyarkatla kaplanmış selüloit filmler ve daha sonra ateșe dayanıklı olanları üretilmiştir. 1950 ve 1960'larda ise günümüzde kullanılan polyester tabanlı filmler üretilmiş ve sonuç olarak cam levhalar kullanılmaz olmuștur (Kılıç, 2002, 22- 27).

\section{Fotoğrafın Yapısı ve Estetiği}

Bir çoğaltım aracı olarak fotoğraf, insanların ve nesnelerin görüntülerini yeniden ve yeniden üreterek çoğalmakta ve 1800 'lü yılların ikinci yarısından itibaren teknik gelişmeler sayesinde hayatın her alanına yayılmıştır.

Fotoğraf -yakın çekimle ve uzaktan yakalama kapasitesiyle- görülebilir olanın alanını muazzam ölçüde genişletmiştir (Sontag, 2011, 138) Fotoğraflar, bakışın 
yadsınamaz kanıtlarıdır. Fotoğrafik kopya, yaratıcısının bakışının sonucu olmasının ötesinde, bu bakışın kâğıt üzerinde somutlașmasıdır (Bodur, 2005, 57).

Derman'a (1991, 62-63) göre; kişiyi fotoğraf çekmeye teşvik eden şey bahsi geçen karanlık kutunun sahip olduğu gizemdir. Karanlık kutunun üzerinde denetimi sağlayan fotoğrafçı, aygıtın girdi ve çıktıları üzerinde hâkimiyet kurar. İşleten, aygıtın dışsal özelliklerini kullanarak ona yön verirken, diğer taraftan da aygıtın programının barındırdığı içsel özelliklerin egemenliği altında çalışmasını sürdürmektedir.

Fotoğraf, mimetik sanatların en gerçekçi, dolayısıyla en kolay icra edileni olmak gibi olumsuz bir üne sahiptir. Fotoğraf, modern dönemin duyarlılığının sürrealistlerin eline geçmesinin sebebiyet verdiği yüzyıllık devasa geçmişine dayanan tehditleri, yüklenerek yoluna devam etmiş tek sanattır (Sontag, 2011, 61). Bugünün sanat ve fotoğraf arasındaki ilişkilerini belirleyen şey, aralarına sanat eserlerinin fotoğrafa aktarılması nedeniyle girmiş olan ama gereği yerine getirilmemiş gerilimdir (Aydemir, 2013, 25). Fotoğraf başlı başına bir sanat formu olmasa bile, her türlü konusunu sanat eserine çevirme gibi özgül bir kapasiteye sahiptir. Fotoğrafın bir sanat olup olmadığı meselesinin yerini, artık fotoğrafın sanatlara yeni hedefler bildirmesi gerçeği almıştır (Sontag, 2011, 178).

Fotoğraf hakkında günümüzde yaygın varsayımlar iki yaklaşım altında incelenebilir: Bunlar, mekanik yapısından dolayı gerçekliğin güvenilir bir belgeleyicisi olması ve Fotoğrafın teknik süreç içinde insan müdahalesine gerek olmamasından ötürü kazandığı güvenilirlik. Belirli sınırları ve çerçevesi olan fotoğraf görüntüsünün, yaşamı oluşturan sürekli ve çerçevelenmemiş deneyimlere oranla farklılığın gözden kaçmasına neden olmaktadır. Ancak okur-yazar bir izleyici, fotoğraf ile olan etkileşimi sırasında söz konusu ortamın semantik ve ontolojik sınırlılıklarını göz önünde bulundurur. Fotoğraf ortamın okunabilirliği ancak ortamın sınırlılıklarının iyi tanınmasıyla mümkündür. $\mathrm{Bu}$ yüzden fotoğrafik görüntünün okunması bir öğrenme süreci gerektirmektedir. Fotoğraf çekildiği an zaman ve mekân ile ilgi bir seçimin yapılmış olmasını gerekli kılar. Fotoğrafik görüntünün ortaya çıkmasına aracılık eden bu iki seçim, yaşanan süreklilik içinden yapılan bir seçimdir. Çünkü görüntülenecek konu bu fotoğrafik zaman ve mekânın kesiştiği noktada bulunur. $\mathrm{Bu}$ anlamda her fotoğraf biricik sayılabilir, zira fotoğraf görüntüsüne konu edilen gerçeklik fotoğraflanan an'dan önce ve sonra değişim içindedir (Derman, 1991, 71-74). Bu biricik olma özelliği ile fotoğrafın güvenirliliği dijital fotoğrafçılığın imkanlarıyla biraz sarsılmış görülebilir ancak güvenilir bir belgeleyici olma özelliğini sürdürmektedir.

Bir fotoğraf hem sahte bir varlığı hem de orada bulunmamayı yansıtan bir göstergedir. Fotoğrafın endüstrileşmesi, toplumu idare etmenin akılcı usullerine hızla uyum sağlamıştır. Fotoğraflar, içinde yaşadığımız çevrenin genel malzemesinin bir parçası olmuştur; bir anlamda gerçekçi sayılan indirgemeci gerçeklik anlayışının birer ayracı ve doğrulayıcı aracı haline gelmiștir (Sontag, 2011, 27).

Fotoğraf sonuç olarak, durağan tek bir karede ortaya çıkan bir bütünlüktür. Fotoğrafın durgun tek karesi bulunuşundan beri çoğaltım aracıdır. Fotoğrafın her zaman çoğaltılabilen bir negatifi vardır. Bu negatiften, aynı boyut ve teknik özelliklere sahip binlerce fotoğraf çoğaltılabilir. Fotoğraf, sanatın ortamına bu temel özelliğini koruyarak girmiştir. Fotoğrafın yüz elli yılı aşan gücünü de onun çoğaltılabilir olmasında aramakgerekmektedir (Kılıç, 2007,32). Günümüzde bu negatif veya pozitif 
film saklama malzemeleri yerini hızla dijital depolama ortamlarına terk etmiştir. Artık o tek kare sonsuz sayıda ve sonsuz değişiklikle tekrar tekrar çoğaltılarak dijital ya da yüzey baskı ortamlarında seyirciye sunulabilmektedir. Aynı zamanda geçmişten bugüne kadar olan süreçte görüntülerin saklandığı bu filmler de (negatif-pozitif) dijital tarayıcılar aracılığı ile dijital dünyaya aktarılarak ta saklanabilmektedir. Dijital teknolojilerin yarattığı sınırsız çeşitlilikteki bu imkanlardan belki de en yoğun yararlanan alan ise haber fotoğrafçılığıdır denebilir.

\section{Haber Fotoğrafçılığı}

19.yüzyılın ikinci çeyreğinin başlarında yeni bir sanat dalı ve teknoloji olarak ortaya çıkan fotoğraf, 19. Yüzyılın ikinci yarısından itibaren haber-röpörtaj, Toplumsalgerçekçi, Doğa-belgesel, deneysel vb. farklı birçok tavır ve yaklaşımlarla günlük yaşamın içine girmeye başlamıştır (Ceyhan, 2003, 41-42).

Gazetecilik anlayışı ile sosyal çevrenin belgelenmesi 1853 yılında Kırım Savaşı sırasında başlamıştır (Kanburaoğlu, 2013, 43). Kırım Savaşı'nı belgeleyen James Robertson, yardımcısı Marcus Sparling ile birlikte yaklaşık 360 adet savaş fotoğrafı çekmiştir (Ceyhan, 2003, 43-47) Fenton'un fotoğrafları Illustrated London News'de tahta oymalardan yapılan gravürler biçiminde basılmıştır. Böylelikle, resimli gazete ve derginin ilk adımları atılmıştır (Kanburaoğlu, 2013, 48).

Çağdaş basın fotoğrafçılığının doğuşu 1920'li yıllara rastlar. Tahta klişelerle basılan ilk fotoğraflar Harper's Weekly, Gelason's Pictorial, Drawing Room Companion ve Harper's Magazine dergilerinde yer almıştır. Bu baskılar bir süre sonra gazetelerde de görülmeye başlanmıştır (Yüksel, 2001, 1-3).

James Robertson ve Felice Beato, İngiliz Ordusunun resmi fotoğrafçlları olarak İngiliz koloni savaşlarını özellikle de 1857-1858 yılları arasında yaşanan Hint isyanını görüntülemişlerdir. Haber fotoğrafçılığının diğer önemli ismi Fronçois Aubert, 1860 yılındaki Meksika İç Savaşı'nı konu alan fotoğraflar belgeseli hazırlamış, aynı zamanda İmparator Maximilien'in infazını da görüntülemeyi başarmıştır (Kanburaoğlu, 2013, 49).

Fotoğrafın etkinliğinin artmasıyla, haberde olayları fotoğraflı aktarmak için kıyasıya bir rekabet bașlamıștır (Kanburaoğlu, 2013, 51). 1880 yılında Jacobs Riis'in flash kullanarak New York'un arka sokaklarında cüzzamlı hastaları çektiği fotoğraflar, Evening Sun gazetesinde basılmasının ardından konut sorununa çözüm bulunması yönünde etkili olmuştur (Yüksel, 2001, 3).

1900 ile 1920 yılları arasında fotoğrafçılık alanında yaşanan gelişmeler sayesinde haber fotoğrafçılığı daha kaliteli bir șekilde yapılabilmiş ve son derece estetik fotoğraflar elde edilmiştir. I. Dünya Savaşıı'nın sonunda Amerika'da gazete çağı başlamıştır. 1919 yılında yeni New York Illustrated Daily News, milyonluk bir tiraj oranı yakalayarak 1930'lardaki haber fotoğrafçılığının temellerinin atılmasını ve fotoğraf dergilerinin yükselmesini sağlamıștır (Kanburaoğlu, 2013, 66).

Presse ve Berliner İllustrirte Zeitung adlı Alman dergileri model alınarak kurulan Life ve Look dergileri ise basın fotoğrafçılığının gelişimine önemli katkılarda bulunmuştur 1920'lerin başında kurulan Wide World Photos, İnternational News Pictures ve Acme News Picture gibi ajansların ardından 1927 yılında da Associated Press fotoğraf servisine başlamıştır (Yüksel, 2001, 4) 
Kırım Savaşı, Amerikan İç Savaşı, I. Dünya Savaşı, 1920’ler Nazi Almanya'sı ve II. Dünya Savașı'nı yakından gören fotoğraf, 60’lı ve 70’li yıllarda Vietnam savaşını aynı zamanda Latin Amerika'da, Afrika'da ve Asya'da ortaya çıkan ulusal kurtuluş mücadelesini ilk elden hafızalara kazımıştır.

\section{Haber Fotoğrafının Nitelikleri}

Haber fotoğrafının en önemli işlevi bir mesaj taşıyor olmasıdır. Bilinmeyeni anlatmaktan öte doğrudan gösterme imkânına sahip olan haber fotoğrafi, olayı tanıtıcı ve öğretici bir role sahiptir. Haberi destekleyen bir unsur olarak fotoğraf, taşıdığı görsel malzemeyle doğru orantılı olarak açıklayıcı bir işlev görmektedir.

Seçilmiş bir an ve zaman dilini yansıtan fotoğraf, onu izleyeni etkileyecek niteliğe sahip olmalıdır. İzleyicide/okuyucuda duygusal bir iz bırakmalıdır. Bir belge olması itibariyle haber fotoğrafı, geçmiş ile gelecek arasında güçlü bir bağ kurmaktadır.

Haber fotoğrafı yaşamın içerisinde insanla ilgili her şeyi kendine konu olarak seçmektedir. Haber fotoğrafı gerçeklik, açıklık, tarafsızlık ve hareket gibi unsurların yanı sıra bünyesinde, zıtlık, denge, orantı uygunluk, bütünlük ve detay gibi önemli nitelikleri de barındırmaktadır.

Picture Post'un ünlü fotoğrafçısı Tim Gidal'e göre, "iyi bir fotoğraf muhabiri aynı zamanda iyi bir belgesel yönetmenidir. Hiçbir zaman fotografik etki uğruna olmayan bir şeyi yakalamaz. Fakat gerçekten olan bir şeyi sonradan tekrar etmek gayet geçerlidir (Aktaran: Hartley ve Renie, 2002, 122).

Haber fotoğrafçıları yüzlerce görüntü fırsatı ve olanağı arasından kendi seçtiği bakış açısı ile fotoğrafını çeker. Haber fotoğrafları gazete sayfasının estetiğine katkı sağlarken diğer taraftan haberin içeriğini desteklemektedir. Haberin doğruluğunun bir kanıtı olarak kabul edilmektedir. Günümüzde ise haber fotoğrafının ya da görüntüsünün insanları etkileme gücü aynı zamanda haberin gerçekliğini ölçen bir araç haline gelmiştir (Soygüder, 2013, 1656)

İyi bir haber fotoğrafı yaşanan anın bir parçası olarak okuru etkilemeli ve heyecanlandırmalıdır. Kullanılan fotoğraflarda "hareket" çok önemlidir. Hareketi yansıtan fotoğraflar okurun ilgisini çekmektedir. Heyecan uyandıran fotoğraflar daima en çok tüketilen fotoğraflardır. Dramatik açılar, çerçeveleme ve aydınlatma fotoğrafın etkisini arttırır ve okurun ilgisini çeker. Fotoğraf teknik açıdan kötü ise içerik ne kadar önemli olursa olsun o fotoğraf gerekli etkiyi oluşturmaz (Soygüder, 2013, 1667)

Manipüle edilmemiş ve tarafsız olması istenen haber fotoğrafı, habere özgü olan, Ne? Nerede? Ne Zaman? Nasıl? Neden? Ve Kim? Sorularının yanıtını vermelidir. Fotoğrafın diğer dallarından ayrı olarak haber fotoğrafı çoğu zaman anında gelişmektedir. Haber fotoğrafı bir yazıyı tamamlamakla kalmaz, olayı detaylandırır. Burada önemli olan okuyucunun duygu ve düşüncelerine seslenen yalın fotoğraflar vererek haberi gerçekçi bir biçimde aktarmaktır (Kanburoğlu, 2013, 259)

Ayaklanmalar, protestolar ve bombalamalar diğer rutin haberlerin aksine en iyi açıyla çekilmiş çok sayıda fotoğrafla birlikte sunma eğilimine sahiptir (Tarrant, 1998, 122)

Kritik an haber fotoğrafçılığında patlamalar, yangınlar, araba, tren ve uçak kazaları, kuşatmalar ve işgaller ve bu tür trajedileri ve şanssızlıkları içermektedir. 
Bir haber fotoğrafçısının anı yakalamadan önce kendine bazı sorular yöneltmesi gerekmektedir:

- Doğru objektif hangisi?

- Bulunulan nokta doğru mudur?

- Bu noktadan yapılacak çekimler olayı doğru anlatmakta mıdır?

- Farklı açılar farklı anlatımı olan fotoğraflar verir mi?

- Kullanılan odak uzunluğu bulunulan nokta ve olay için uygun mu?

- Bulunulan nokta güvenli midir?

$\mathrm{Bu}$ haber fotoğrafı tipi, haber fotoğrafçısının en çok zorlandığı ve tecrübeli olması gereken tiplerdendir. Çekilen an ne olursa olsun tüm bu fotoğrafların ortak özelliği bir kişinin ya da olayın görüntüsünün yakalamak ve dolayısıyla, fotoğrafa bakan kişinin zihninde unutulmaz bir iz bırakmaktır (Kanburoğlu, 2013, 262).

\section{Joseph Pulitzer ve Pulitzer Ödülleri}

10 Nisan 1847'de Macaristan'da doğan Pulitzer, 1878 yılında ST. Louis PostDispatch'ın sahibi ve gazetecilik sahnesinde ilerleyen önemli bir şahsiyet haline gelmiştir. Pulitzer, hükümetin yozlaşmasını, zengin vergi kaçakçılarını ve kumarbazları suçlayan makalelere ve baş makalelere yer vermiştir. Daha sonraki dönemlerde yaşadığı sağlık problemlerine rağmen, çalışmalarını devam ettirmiş, The Newyork World'ün editörlük politikasını, kapsamını ve formatını yenilemiştir. Post-Dispatch'in satışlarını arttıran tekniklerin bazılarını burada da uygulamıştır. Kamudaki ve özel yaşamdaki yozlaşmaya savaş açmıştır. Haber sütunlarını sansasyonel konularla doldurmuştur. İlk kez çok sayıda fotoğrafa yer vermiş ve dikkat çekici faaliyetlerde bulunmuştur. Tarihçilerin görüşüne göre Pulitzer'in sansasyonel gazeteciliğe başvurması kamu hizmetinde gösterdiği başarılarıyla dengelenmiștir. Hükümetteki ahlak dışı yozlaşmalara karşı cüretkâr ve genellikle başarılı savaşlar açmıştır. Satın aldığı gazeteyi üç yıl içerisinde o ana kadar çıkartılmış olanlar arasında en tercih edilen gazete pozisyonuna getirmeyi başaran Pulitzer, sansasyonelizmin babası olarak tanınmıştır. Çünkü gazetesinin sayfasını kan ve cinayetlerle doldurmuștur. 19. Yüzyılın son yıllarında Joseph Pulitzer, Amerikan Gazeteciliği'nin en önemli temsilcisi olmuştur. Macaristan doğumlu, boyun eğmez bir şahsiyet olarak Pulitzer, gazete yayıncılarının en beceriklisi, dürüst olmayan hükümetlere tutkuyla savaş açan bir insan, gazete satışı mücadelesinde sansayonellikten ürkmeyen, rekabetçi ve mesleğine büyük katkılar yapan ön sezili bir gazetecidir (Kanburoğlu, 2013, 101- 105).

Pulitzer, mükemmeliyete davet olarak 1094'de kaleme aldığı vasiyetinde gazetecilik dalında dört, edebiyat ve tiyatro alanında dört, eğitim için bir ve dört tane de yabancı ülke bursu belirlemiştir. Edebiyat ödülleri, bir Amerikan romanına, New York'ta sahnelenen orijinal bir tiyatro oyununa, Birleşik Devletler üzerine yazılmış tarihi bir kitaba ve haberi yapılan bir kamu hizmeti tarihine verilmesi öngörülmüștür. 1917 yılından bu yana Pulitzer Ödül Kurulu, kurucusunun ruhuna ve amacına sadık kalarak ödül sayısını 21'e çıkarmış ve şiir, müzik ve fotoğraf kategorileri de eklemiştir (http://www.pulitzer.org/historyofprizes).

Pulitzer 'in 1912'de hayatını kaybetmesinden bir yıl sonra Colombia Üniversistesi, gazetecilik fakültesi kurulmuş, verdiği emri emanet ettiği danışmanlar kurulunun denetimi altında 1917'de ilk kez Pulitzer Ödülleri verilmiştir. Pulitzer, gazete yayıncılarından oluşturulmuş bir danışmanlar kurulu düşünmüştür. Ancak, buna 
Colombia Üniversitesi başkanı, bilginler, gazeteci ya da editör olmayan seçkin insanlar da katılmıştır. 2000 yılında kurul iki haber yöneticisi, sekiz editör, Colombia Üniversitesi Başkanı ve Colombia Üniversitesi Gazetecilik Fakültesi Dekanı dahil beş akademisyen, bir köşe yazarı ve ödüllerin yöneticisinden oluşmuştur. Bu ödüllerin en önemlisi olan Pulitzer Fotoğraf Ödülü ise 1942'de başlatılmıştır. 1968 yılında bu kategori spot ya da sansasyonel haberlerle, normal haberlere bölünmüştür. Bilgisayarlarla değiștirilmiş fotoğrafların yaygınlaşmasıyla kurul, 1955'de standart fotoğraf kadrajlama ve ton düzeltmesi dışında, içeriği üzerinde oynanan veya değiștirilen hiçbir fotoğraf başvurusunun kabul edilmeyeceğini duyurmuştur. Pulitzer fotoğraf ödüllerinde son yllarda uygulanan kategori, "bir fotoğraf veya fotoğraflardan, bir dizi ya da albümden oluşan siyah beyaz veya renkli bir baş haber fotoğrafının seçkin bir port folyosu" olmuştur. Başlangıçta sadece spot haber fotoğraflarına verilen ödül, 1968 yılından itibaren hikâye fotoğrafına da verilmeye başlanmıştır. Böylece spot ve feature dallarında ödüller bugüne kadar dağıtılmaya devam etmiştir (Kanburoğlu, 2013, 106-107).

\section{Pulitzer Ödüllü Savaş Fotoğraflarının Gösterge bilimsel Çözümlemesi}

Kodlar: Fotoğrafta yer alan başlıca kodlar, dizisel çözümlemede belirtilen göstergelerdir. Kodlar toplumun içinde var olan kültürün ürünüdür. Geçmişte veya kullanılanlar arasındaki anlaşmaya dayanmaktadır.

Dizisel Çözümlemesi: Bir metnin dizisel çözümlemesi, metinde saklanmış olan ve anlamı oluşturan gizli karşıtlıklar modelinin aranmasını içermektedir. Bütün metinlerde ortaya çıkarılabilen, dizgesel ve birbirleriyle ilgisi olan bir tür karşıtlıklar bütünü olmalıdır. Anlam ilişkiler kurmaya dayalıdır ve dildeki anlamın üretimindeki en önemli ilişki karşıtlıklar ilişkisidir. Dizisel yaklaşımı kullanma nedeni kişilerin ne yaptıklarından çok ne anlama geldiklerini bulmaya yöneliktir (Berger, 1993, 26-28)

\section{Iwo Jima'da Yükselen Bayrak (Raising the Flag on Iwo Jima) Fotoğrafının Gösterge Çözümlemesi}

28. Alay 5. Bölüğe bağlı ABD Deniz Piyadeleri 23 Şubat 1945 tarihinde Iwo Jima'da bulunan Suribachi dağının zirvesine Birleşik Devletler bayrağını dikiyor. Stratejik olarak Tokyo'ya 660 mil uzaklıkta bulunan bu nokta, II. Dünya Savaşı sırasında Japonya'ya karşı Pasifikte yürütülen en kanlı savaş alanı olarak tarihe geçmiştir. $\mathrm{Bu}$ fotoğraf, Birleşik Devletler 'de savaşın en dikkate değer ve bilindik sembolü haline gelmiştir. 


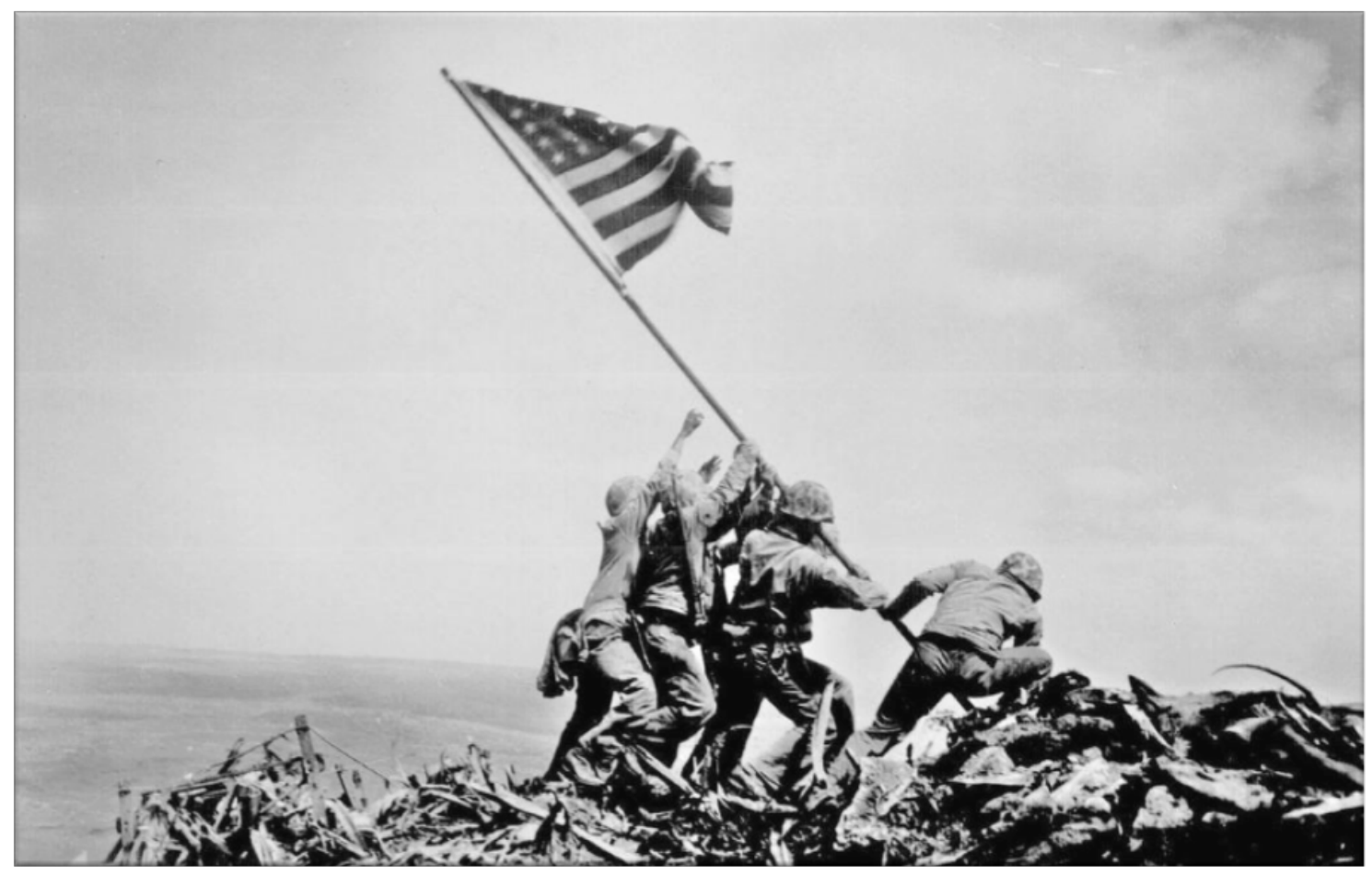

Şekil 1: Iwo Jima'da Yükselen Bayrak.

Fotoğrafın Künyesi:

Fotoğrafçı: Joe Rosenthal

Ajans: Associated Press

Çekim Tarihi: 23 Şubat 1945

Yer: Iwo Jima, Japonya

Fotoğrafının Gösterge Analizi:

Gösterge: Tepeye bayrak diken bir grup asker

Gösteren: Dört asker, dalgalanan Amerikan bayrağı, zirve, gökyüzü, fotoğraf

Gösterilen: Bağımsızlık, zafer, savaşın sonu, kahramanlık, güç

Tablo 1'de ise Thomas Sebeok'a (Aktaran: Parsa, 2007, 6) göre düz anlam ve yan anlam çözümlemesi gerçekleştirilmektedir.

Tablo 1: Fotoğrafin Düz anlam ve Yan anlam dizgeleri.

\begin{tabular}{|c|c|}
\hline GÖSTERGE & II. Dünya Savaşı sırasında Iwo Jima'da çekilen bir savaş fotoğrafı \\
\hline \multicolumn{2}{|r|}{ Birinci Anlam Düzlemi } \\
\hline DÜZ ANLAM & Bir grup askerin bir dağın zirvesine dikmeye çalıştığı bir bayrak imgesi \\
\hline \multicolumn{2}{|r|}{ İkinci Anlam Düzlemi } \\
\hline YAN ANLAM & $\begin{array}{l}\text { Fotoğrafta yer alan bayrak imgesi, sahip olduğu renk ve biçimlerle bir milletin, } \\
\text { belli bir topluluğun simgesi, aynı zamanda bağımsızlığının kanıııdır. } \\
\text { Ancak bu fotoğrafta yer alan bayrak, stratejik öneme sahip bir dağın zirvesinde } \\
\text { yükselirken; düşmana karşı elde edilen kesin zaferi işaret etmektedir. } \\
\text { Aynı zamanda bu bayrak, bulunduğu konum itibariyle güç dengesinin } \\
\text { değiştiğinini, üstünlüğün bir taraftan diğerine evirildiğini sunmaktadır. }\end{array}$ \\
\hline міт & $\begin{array}{l}\text { Bayrak özgürlüğün, zirve başarının bir göstergesidir. Savaş sırasında } \\
\text { zirveye çekilen bayrak ise mutlak zaferi temsil eden bir mittir. Bir } \\
\text { güç gösterisidir. Üstünlüğün ve hâkimiyetin göstergesidir. }\end{array}$ \\
\hline
\end{tabular}

Dizisel Çözümlemesi: Zafer - Yenilgi, Güç - Zayıflık, Yaşam- Ölüm, Asker- Sivil, Bağımsızlık- Esaret, Umut- Karamsarlık, Sevinç- Acı. 
Kodlar: Bayrağın diyagonal duruşu fotoğrafa hareket katmaktadır. Toprağın üstünden gökyüzüne doğru diyagonal yükselen bayrak, canlılık duygusu uyandırmakta; zaferin zirvede bulunanlar için çok yakın olduğuna dikkat çekmektedir.

\section{Metafor ve Metonimi Kullanımi:}

Metefor: Cesaretle yol alındığında sonunda zafere ulaşılacağına işaret etmektedir. Metonimi: Ölen askerler yerine yükselen bayrak gösterilmektedir.

\section{Andrew Lopez'in “Küba Infazları” Fotoğrafının Gösterge Çözümlemesi}

Bu fotoğraf, United Pres International'in haber fotoğrafçısı Andrew Lopez'e 1960 yılında Pulitzer Ödülü kazandıran ve Küba İnfazlarını belgeleyen bir fotoğraf serisine aittir. Fotoğrafta, Küba Devrimi sırasında Batista Ordusunda görevli eski bir ordu mensubu olan Jose Rodriguez, bir papaza idam edilmeden önceki son isteğini iletmektedir. Rodrigez, 1 dakika süren bir mahkemenin ardından savaş suçlusu olarak mahkûm edilmiş, ardından idam mangasının önüne çıkartılmıştır.

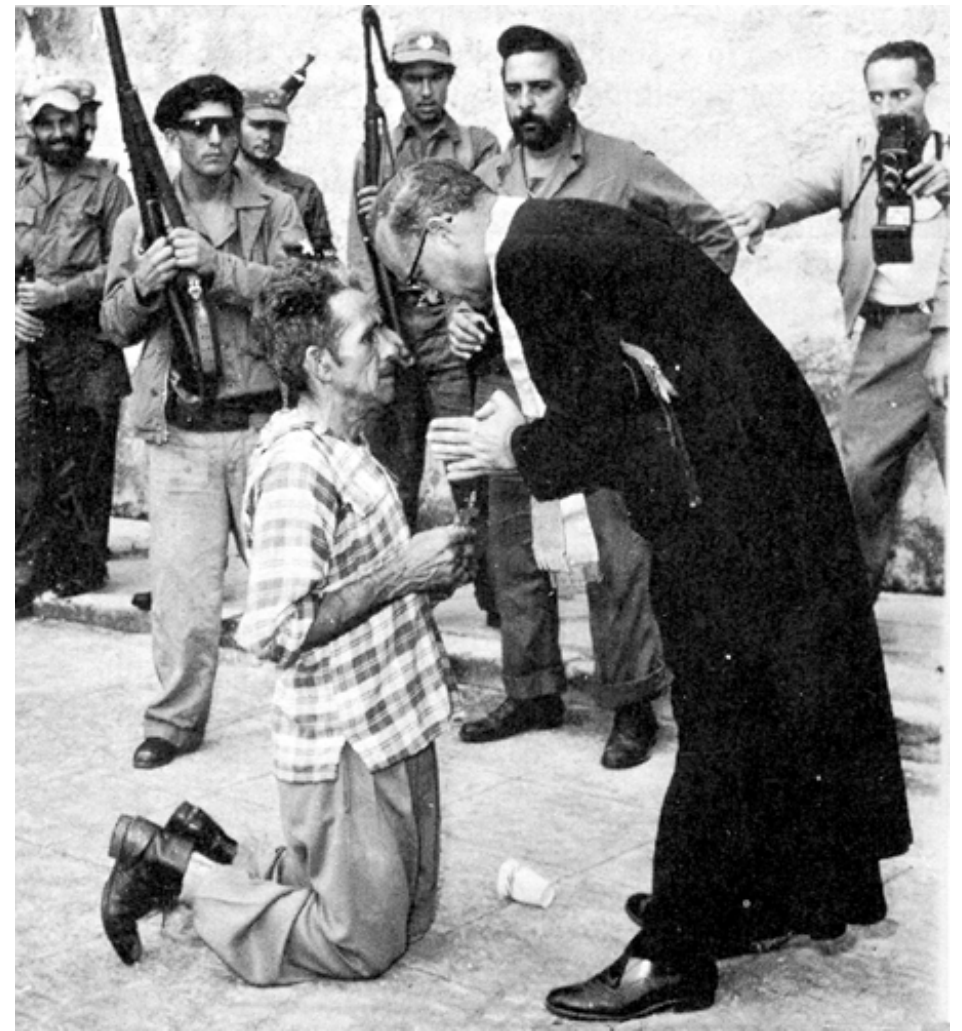

Șekil 2: Küba Infazları.

Fotoğrafın Künyesi:

Fotoğrafçı: Andrew Lopez,

Ajans: United Press International

Çekim Tarihi: 17 Ocak 1959,

Yer: Matanzas, Cuba

Fotoğrafının Gösterge Analizi:

Gösterge: Bir grup asker önünde papaza son isteğini bildiren bir suçlu

Gösteren: Bir papaz, mahkûm, silah, askerler, gazeteci, haç, fotoğraf

Gösterilen: Suç, Mahkeme, Adalet, İdam, Pișmanlık, Ölüm

Tablo 2'de ise Thomas Sebeok'a (Aktaran: Parsa, 2007,6) göre düz anlam ve yan anlam çözümlemesi gerçekleştirilmektedir. 
Tablo 2: Fotoğrafın Düzanlam ve Yananlam dizgeleri

\begin{tabular}{|c|c|}
\hline GÖSTERGE & Küba Devrimi sırasında çekilmiş bir haber fotoğrafı \\
\hline \multicolumn{2}{|r|}{ Birinci Anlam Düzlemi } \\
\hline DÜZ ANLAM & İşlediği suç nedeniyle ölüme mahkûm edilmiş bir adamın son isteği \\
\hline \multicolumn{2}{|r|}{ İkinci Anlam Düzlemi } \\
\hline YAN ANLAM & $\begin{array}{l}\text { Fotoğrafta yer alan elleri silahlı askerler, gücü elinde bulunduran iktidarı } \\
\text { temsil ederken, mahkûmun dizlerinin üstünde oluşu yenilgiyi kabul edişinin } \\
\text { ve hakkında verilen kararı kabullendiğinin bir göstergesidir. Mahkûmun elinde } \\
\text { tuttuğu haç, sahip olduğu inancı simgelerken, papazın ona doğru şefkatle } \\
\text { eğilmesi de günahlarından arınmak için son bir fırsatı işaret etmektedir. } \\
\text { Fotoğrafçı ise bu anı belgeleyerek iktidarın otoritesini onaylamaktadır. }\end{array}$ \\
\hline міт & $\begin{array}{l}\text { Din adamı, ahlakı, iyiliği doğru ile yanlışı; asker, üretimi elinde } \\
\text { bulunduran güç sahiplerini ve onların koyduğu kuralları ve } \\
\text { düzeni korumayı, silah ise ölümü temsil eden mitlerdir. }\end{array}$ \\
\hline
\end{tabular}

Dizisel Çözümlemesi: Ölüm - Yaşam, Suç - Ceza, Asker - Sivil, Günah - Bağışlanma, Savaş - Barış, Sevinç- Acı.

Kodlar: Cübbesi içinde mahkûma şefkatle eğilerek onun son isteğini dinleyen peder, yaratıcının temsilcisi olarak ona cesaret vermektedir Adaletin sağlanması bu mahkûmun idam edilmesiyle sağlanacaktır. Askerler bu küçük ayinin ardından infazı gerçekleştirerek düzeni yeniden sağlamayı amaçlamaktadırlar.

\section{Metafor ve Metonimi Kullanımı:}

Metefor: Savaş suçu işleyen herkes cezalandırılmalıdır.

Metonimi: Savaşın neden olduğu tüm acıların sorumlusu, Batista Ordusu'na mensup bu adamdır.

\section{"Napalm Kızı" (The Napalm Girl) Fotoğrafının Gösterge Çözümlemesi}

Vietnam Savaşı sırasında Napalm bombasından kaçan çocukları gösteren bu fotoğrafta, çerçevenin ortasında kameraya doğru koşan ve Napalm Kızı, olarak bilinen Phan Thị Kim Phúc isimli bir kız çocuğu bulunmaktadır. Bu fotoğraf, bombalama kurbanlarını tüm çıplaklığıyla tasvir etmesi bakımından, o dönemde AP'nin geçtiği haberler içinde benzeri görülmemiş bir görsel dile sahiptir. Bu fotoğrafın 20. yüzyllın en unutulmaz fotoğraflarından biri olduğu düşünülmektedir. 


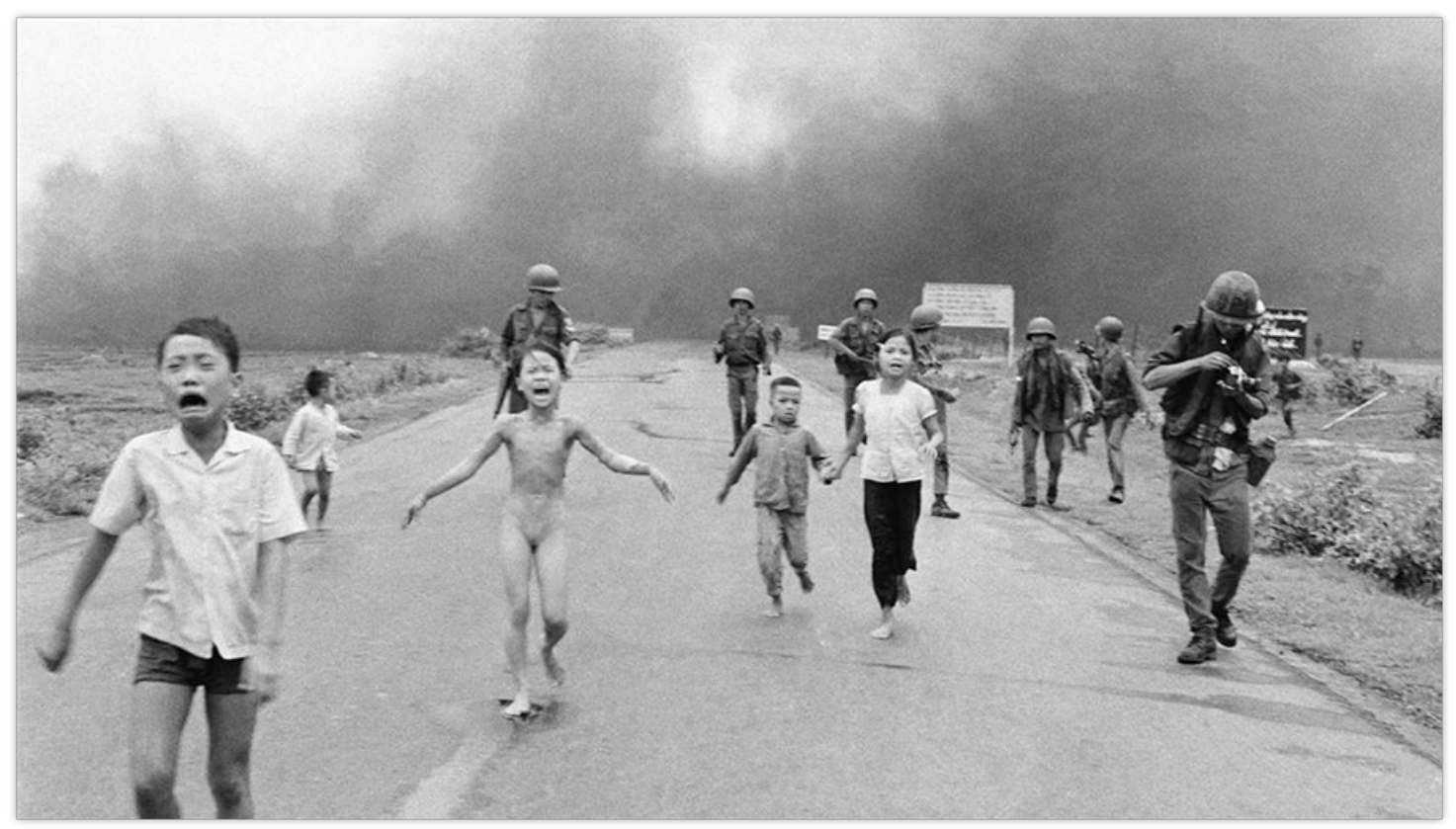

Şekil 3: Napalm Kızı

Fotoğrafın Künyesi:

Fotoğrafçı: Nick Ut

Ajans: Associated Press

Çekim Tarihi: 08 Haziran 1972

Yer: Trang Bang, Vietnam

\section{Fotoğrafının Gösterge Analizi:}

Gösterge: Bir grup askerin önünde koşmakta olan Vietnamlı çocuklar

Gösteren: Askerler, kız ve erkek çocuklar, uzayıp giden bir yol, duman bulutu

Gösterilen: Ölüm, korku, savaş, umutsuzluk, karamsarlık, çaresizlik

Tablo 3'te ise Thomas Sebeok'a (Aktaran: Parsa, 2007, 6) göre düz anlam ve yan anlam çözümlemesi gerçekleştirilmektedir.

Tablo 3: Fotoğrafın Düzanlam ve Yananlam dizgeleri

\begin{tabular}{|c|c|}
\hline GÖSTERGE & Vietnam'da Napalm bombası atıldıktan hemen sonra çekilen bir haber fotoğrafı \\
\hline \multicolumn{2}{|r|}{ Birinci Anlam Düzlemi } \\
\hline DÜZ ANLAM & Bombanın öldürücü etkisinden kaçmakta olan korkmuş Vietnamlı çocuklar. \\
\hline \multicolumn{2}{|r|}{ İkinci Anlam Düzlemi } \\
\hline YAN ANLAM & $\begin{array}{l}\text { Fotoğrafın tam ortasında çıplak bir halde kaçmaya çalışan kız çocuğu, } \\
\text { savaşın yıkıcı yüzünü tüm çıplaklığıyla ortaya koymaktadır. Arkada } \\
\text { yürümekte olan askerlerin aksine, çocuklar korku dolu bakışlarla son } \\
\text { bir kez yaşama tutunmaya çalışmaktalar. Yüzlerindeki korku ve dehşet, } \\
\text { tüm masumiyetlerini bir daha elde etmemek üzere geride bıraktıklarını } \\
\text { işaret etmektedir. Umut yerini korkuya ve çaresizliğe bırakmıştır. }\end{array}$ \\
\hline міт & $\begin{array}{l}\text { Çocuk, umudun, geleceğin, masumiyetin, bomba ölümün, çıplaklık, } \\
\text { savunmasızlığın göstergesidir. Savaşın ortasında yaşama tutunmaya çalışan } \\
\text { çıplak bir çocuk yok olan umutların ve insanlık suçunu işaret etmektedir. }\end{array}$ \\
\hline
\end{tabular}

Dizisel Çözümlemesi: Çocuk - Yetişkin, Çıplak - Giyinik, Korku - Cesaret, Asker Sivil, Yaşam - Ölüm, Masumiyet - Hırs, Suç - Ceza, Gözyaşı- Mutluluk, Panik- Sükûnet. 
Kodlar: Uzayıp giden bir yolda arkada bıraktıkları ölümün her an onları da yakalayacaklarından endişe duyan birkaç masum çocuk, savaşın en acımasız haline de tanık olmaktadırlar. Masumiyetin ve geleceğin göstergesi olan çocukların yüzündeki dehşet ve yaşadıkları korku, insanlığın sahip olduğu tüm değerlerinde yok olup gittiğini işaret etmektedir.

\section{Metafor ve Metonimi Kullanımı:}

Metefor: Savaş, insanların geleceğini yok eder.

Metonimi: Savaş, çocukları öldürmekle geleceği de yok etmektedir.

\section{Sonuç}

$\mathrm{Bu}$ çalışmada; fotoğrafın gerçekliğin güvenilir bir belgesi olma özelliği ile haber fotoğrafçılığının en önemli işlevinin bir mesaj taşıyor olma özelliği savaş fotoğrafları üzerinden ele alınmıștır. Doğrudan gösterme imkânına sahip olan haber fotoğrafı, güvenilir bir belge olmasının yanı sıra olayı tanıtıcı ve öğretici bir güce de sahiptir. Haberi destekleyen bir unsur olarak fotoğraf; çekildiği anın tüm mesaj içeriğini hedef kitleye güvenilir, doğru, etkileyici ve güçlü bir şekilde verebilmesi önemlidir.

Associated Press'in haber fotoğrafçısı Joe Rosenthal tarafından çekilen "Iwo Jima'da Yükselen Bayrak" (Japonya, 1945) Fotoğrafı, Amerika Birleşik Devletleri ile Japonya arasında yaşanan en kanlı savaşın sembolleșen görüntüsüdür. Çekildiği anın tüm mesaj içeriğini doğrudan ve etkili bir şekilde aktarmaktadır. Zafer- Yenilgi, GüçZayıflık, Yaşam- Ölüm, Asker- Sivil, Bağımsızlık- Esaret, Umut- Karamsarlık, SevinçAcı gibi birçok zıtlıklar fotoğrafın dizisel çözümlemesinden ortaya konabiliyor.

Bir diğer Pulitzer Ödüllü fotoğraf "Küba İnfazları" (Küba, 1959) ise; United Pres International'in haber fotoğrafçısı Andrew Lopez tarafından çekilmiş, Küba devrimi sırasında yaşanan olayları anlatması açısından önemli ve ödüle değer görülmüş bir fotoğraftır. Fotoğrafta, Batista Ordusunda görevli eski bir ordu mensubu olan Jose Rodriguez bir papaza son isteğini iletmektedir ki; çok kısa süren bir mahkemeden sonra savaș suçlusu olarak idam mangasının önüne çıkmıștır. Bu fotoğrafta da ÖlümYaşam, Suç- Ceza, Asker- Sivil, Günah- Bağışlanma, Savaş- Barış, Sevinç- Acı gibi çok sayıda zıtlık olduğu dizisel çözümlemesinden anlaşılmaktadır.

Makaleye konu son fotoğraf, Associated Press'in haber fotoğrafçısı Nick Ut tarafından Vietnam savaşı sırasında çekilen "Napalm Kızı" (Vietnam, 1972) fotoğrafıdır. Pulitzer Ödüllü bu fotoğraf, bombardıman kurbanlarını tasvir etmesi ve yaşanan insanlık dramını tüm çıplaklığıyla ortaya koyası bakımından önemlidir. Çocuk- Yetişkin, Çıplak- Giyinik, Korku- Cesaret, Asker- Sivil, Yaşam- Ölüm, Masumiyet- Hırs, SuçCeza, Gözyaşı- Mutluluk, Panik- Sükûnet gibi bir arada bulunması imkânsız gibi görünen birçok zıtlık bu fotoğrafta da görülmektedir.

Pulitzer Ödüllü her üç fotoğraf da savaşı konu almaktadır. Bununla birlikte sanki savaşın ve sonuçlarının tüm dehşetini ortaya koyarken, hâkim gücün destansı görüntüsü oldukça sakin bir izleğe sahiptir. Özellikle, dizisel çözümlemelerde ortaya konmuş olan zıtlıkların her üç fotoğrafın etkisine yüksek düzeyde katkı sağladığı söylenebilir. Bu zıtlıklar, fotoğrafların taşıdığı anlamları güçlü kılarken izleyici üzerinde şiddetli bir etki yaratmasında da önemli olduğu söylenebilir. Fotoğraflar; çok özenerek planlanmış ve yüksek çekim tekniğine sahip görünmemekle beraber, yansıtılan "an" keskin bir etkiye ve süreci tüm çıplaklığı ile ortaya koyan şiddetli bir güce yani izleyiciyi delip geçen olağanüstü bir tesire sahiptir. 
Göstergebilimin öncülerinden Roland Barthes bu etkiyi "Studium" ve "Punctum" kavramlarıyla açıklamaktadır. Barthes'a göre studium; fotoğrafın incelenmesi sonucu bulunan her türlü politik, kültürel, tarihi, estetik ya da teknik anlam ve yorum bağlamında fotoğraftaki simgeler ve semboller ile anlamlar arasında fikir yürütmedir. Bir çeşit kodlama veya anlam kazandırma sürecini ifade etmektedir. Punctum ise; fotoğraftan beklenmedik şekilde çıkarak izleyici delip geçen kodlanmamış, kontrol edilemeyen bir nevi sarsıcı bir etkidir (Ertan ve Sansarcı, 2016, 50-53).

Pulitzer Ödüllü her üç fotoğrafta göstergebilimsel yöntemle yapılan görsel analizleri, Barthes'ın "Studium" olarak adlandırdığı sürece dahil edebiliriz. Bununla birlikte her üç fotoğrafta aynı kültür coğrafyasından olmayan insanlar tarafından bile evrensel bir şekilde algılanabilen o şok edici, çarpıcı ve keskin etkiyi "Puctum" kavramının "izleyici delip geçen" olağanüstü etkisiyle açılklamak mümkün görünüyor. Bu tür fotoğraflarda; fotoğrafı çekenin, anın yaşandığı atmosferi kendi içinde ne kadar yaşayabildiği ile "izleyici delip geçen" o olağanüstü etkiyi yakalaması arasında bir bağlantı olabilir. Bu bağlamda haber fotoğrafçısının gerekli tüm teknik bilgi birikiminin yanında anı görüntüleyeceği atmosferi yaşaması gerekmektedir.

\section{Kaynakça}

Aydemir, C. (der.). (2013). Fotoğraf Neyi Anlatır. İstanbul: Hayalperest Yayınevi

Berger, A. A. (1993). Kitle İletişiminde Çözümleme Yöntemleri. Ulutak, N. Tunç, A. (Ed.) Eskișehir: Anadolu Üniversitesi Eğitim Sağlık ve Bilimsel Araștırma Çalışmaları Yayınları

Bodur, F. (2005). Fotoğrafın Tarihi. Konya: Tablet Yayınları

Ceyhan, Z. (2003). Temel Fotoğrafçılık Bilgileri. Eskişehir: Anadolu Üniversitesi Güzel Sanatlar Fakültesi Yayınları

Derman, İ. (1991). Fotoğraf ve Gerçeklik. İstanbul: Ağaç Yayıncılık

Ertan, G., Sansarcı, E. (2016). Görsel Sanatlarda Anlam ve Algı. İstanbul: Alternatif Yayincllı.

Hartley, J. Renıe, E. (2012) "Bir Kız Hakkında" Fotoğraf Gazeteciliği olarak Moda Fotoğrafçılı̆̆ı (S. Şenel, Çev.) İstanbul Arel Üniversitesi İletişim Çalışmaları Dergisi, 1 (2), 117-143.

Kanburoğlu, Ö. (2013). Haber Fotoğrafçılığı. Ankara: Say Yayınları

Kılıç, L. (2002). Fotoğrafa Başlarken. Ankara: Dost Kitabevi Yayınları

Parsa, A.F. (2007) “Göstergenin Gücü / Gücün Göstergesi: İmge Reklam Bildirilerinde Göstergebilimsel Yaklaşımla Durağan İmgeleri Çözümlemek”, 29 Mayıs- 2 Haziran 2007, VIII. Uluslararası Görsel Göstergebilim Kongresi AISV- IAVS “Görünürün Kültürleri”, İstanbul Kültür Üniversitesi Yayınları, Yayın No: 63, Proceedings Volume II, s. 1149-1161.

Sontag, S. (2011). Fotoğraf Üzerine. (O. Akınbay, Çev.) İstanbul: Agora Kitaplı̆̆

Soygüder, Ş. (2013). Fotoğraf Editörlüğü Kurumu ve Gazeteler İçin Önemi. The Journal of Academic Social Science Studies, 6 (2), 1653-1677.

Tarran, J. (1998). Professional, Press, Editorial and Pr Photohraphy. London: Oxford, Focal Press 
Yüksel, G. (2001). Basın Fotoğrafçılığının Sırları. Lefkoșe: Işık Kitabevi Yayınları İnternet Kaynakları

Topping, S., Gissler S., (2018, 10 Ocak) History of The Pulitzer Prizes http://www. pulitzer.org/historyofprizes adresinden elde edildi. 